\title{
Experimental Investigation of Phase Equilibria in the Bi-Cu-Ge System
}

\author{
Milan Milosavljevic ${ }^{a}(1)$, Milena Premovic ${ }^{a, b *}$, Dusko Minic ${ }^{a}$,Vladan Cosovic ${ }^{c}$, \\ Aleksandar Djordjevica, Milica Tomovic ${ }^{a}$ \\ ${ }^{a}$ University of Priština, Faculty of Technical Science, Kneza Milosa 7, 38220 Kos. Mitrovica, Serbia. \\ ${ }^{b}$ Central South University Changsha, State Key Laboratory of Powder Metallurgy, China. \\ ${ }^{c}$ University of Belgrade, Institute of Chemistry, Technology and Metallurgy, Belgrade, Serbia.
}

Received: April 27, 2021; Revised: July 06, 2021; Accepted: August 12, 2021

\begin{abstract}
Phase diagram of the Bi-Ce-Ge ternary system has been investigated experimentally and thermodynamically extrapolated by using Pandat software. Experimental results were obtained using differential thermal analysis (DTA), scanning electron microscopy (SEM) with energy dispersive spectrometry (EDS), and X-ray powder diffraction (XRD) methods. Examined ternary samples belong to two isothermal sections at 400 and $600{ }^{\circ} \mathrm{C}$ as well as three vertical sections $\mathrm{Bi}-\mathrm{CuGe}, \mathrm{Cu}-\mathrm{BiGe}$, and $\mathrm{Ge}-\mathrm{BiCu}$. No ternary compound has been detected in the equilibrated samples from the selected isothermal sections. Based on the presented experimental data and available literature data, description of the ternary system has been developed. A reasonable agreement between the experimental data and the calculated phase equilibria was obtained. As an example, ternary $\mathrm{Cu}_{80} \mathrm{Bi}_{10} \mathrm{Ge}_{10}$ alloy was selected for solidification simulations according to Scheil and Lever Rule assumptions as well as for simulation of the total fraction of each solid at different temperatures, latent heat, and total heat.
\end{abstract}

Keywords: phase equilibria, ternary $\mathrm{Bi}-\mathrm{Cu}$-Ge system, experimental tests.

\section{Introduction}

In recent period ternary alloys based on Bi-Ge have been attracting notable attention. These alloys are important due to the fact that semiconducting properties can be improved by addition of $\mathrm{Bi}$ to Ge-based materials ${ }^{1}$. It is therefore not surprising that they are extensively used in electrical and electronics industry ${ }^{2-4}$. On the other hand, it is well known that $\mathrm{Cu}$ is the main alloying element in electronic products ${ }^{5-9}$. Our group has, in previous investigations, already assessed ternary systems such as $\mathrm{Bi}-\mathrm{Ge}-\mathrm{Zn}, \mathrm{Ga}, \mathrm{In}, \mathrm{Sn}, \mathrm{Ag}, \mathrm{Sb}^{10-12}$. The $\mathrm{Bi}-\mathrm{Cu}-\mathrm{Ge}$ ternary system is interesting due to the possible application in electronics industry and the fact that it has not been assessed before.

Ternary alloys studied in this work belong to two isothermal sections at 400 and $600{ }^{\circ} \mathrm{C}$ and three vertical sections. The experimental results obtained using differential thermal analysis (DTA), scanning electron microscopy (SEM) with energy dispersive spectrometry (EDS) and X-ray powder diffraction (XRD) were compared with calculated isothermal sections at 400 and $600{ }^{\circ} \mathrm{C}$ and selected vertical sections. For the calculations of the ternary Bi-Cu-Ge system, no new ternary parameters was necessary. Reasonable agreement between the calculated phase diagrams and the experimental data was obtained

\section{Literature Information}

Although we could not find previous studies related to ternary $\mathrm{Bi}-\mathrm{Cu}-\mathrm{Ge}$ system, according to accessible literature

*e-mail: milan.milosavljevicm@gmail.com information, constitutive binary systems have been studied for a long time and their reliable phase equilibrium descriptions are available.

The $\mathrm{Bi}-\mathrm{Cu}$ system is a simple eutectic system consisting of two solid solutions $(\mathrm{Bi}),(\mathrm{Cu})$ and one liquid phase $\mathrm{L}$ with a eutectic reaction close to the bismuth-rich side. The calculated binary Bi-Cu phase diagram is shown in Figure 1.

Besides the liquid phase $\mathrm{L}$, there are six solid phases stable in the $\mathrm{Cu}-\mathrm{Ge}$ system: three are the solid solutions $((\mathrm{Cu}),(\mathrm{Ge})$ and $\xi)$ and the other three are the intermetallic $(\varepsilon(\mathrm{Cu} 0.765 \mathrm{Ge} 0.235), \eta(\mathrm{Cu} 3 \mathrm{Ge})$, and $\theta(\mathrm{Cu} 0.735 \mathrm{Ge} 0.265))$. The binary $\mathrm{Cu}-\mathrm{Ge}$ phase diagram is a complex system with eight invariant reactions, out of which two are peritectic, two eutectic, one peritectoid and three are eutectoid reactions. The $\mathrm{Cu}-\mathrm{Ge}$ phase diagram, calculated using the thermodynamic data established by Wang et al. ${ }^{14}$, is shown in Figure 2 .

The Bi-Ge system is a eutectic system consisting of two solid solutions $(\mathrm{Bi}),(\mathrm{Ge})$ and one liquid phase $\mathrm{L}$ with a eutectic reaction at $271.3^{\circ} \mathrm{C}$ close to the bismuth-rich side. The calculated binary Bi-Cu phase diagram is shown in Figure 3.

A summary of the stable solid phases from the three binary systems is given in Table $1^{16-22}$.

According to the information summarized above, at least seven solid and one liquid $\mathrm{L}$ phase should appear in ternary $\mathrm{Bi}-\mathrm{Cu}-\mathrm{Ge}$ system.

\section{Experimental Procedure}

Ternary alloys for experimental tests were prepared from highly pure $\mathrm{Bi}, \mathrm{Cu}$ and $\mathrm{Ge}$ (99.999 at. \%), produced by Alfa 
Aesar, Germany. All samples were melted and re-melted five times in an induction furnace, to achieve homogeneity. The average weight loss of the samples during melting was

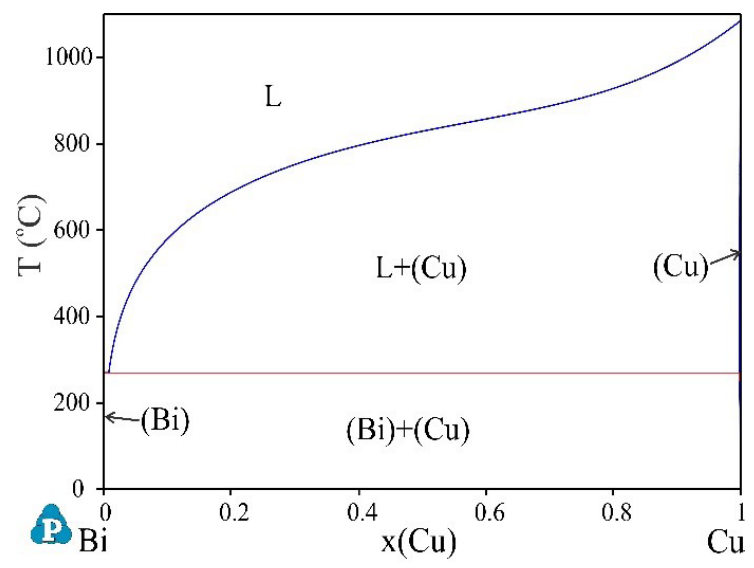

Figure 1. Bi-Cu phase diagram calculated using thermodynamic data established By Teppo et al. ${ }^{13}$.

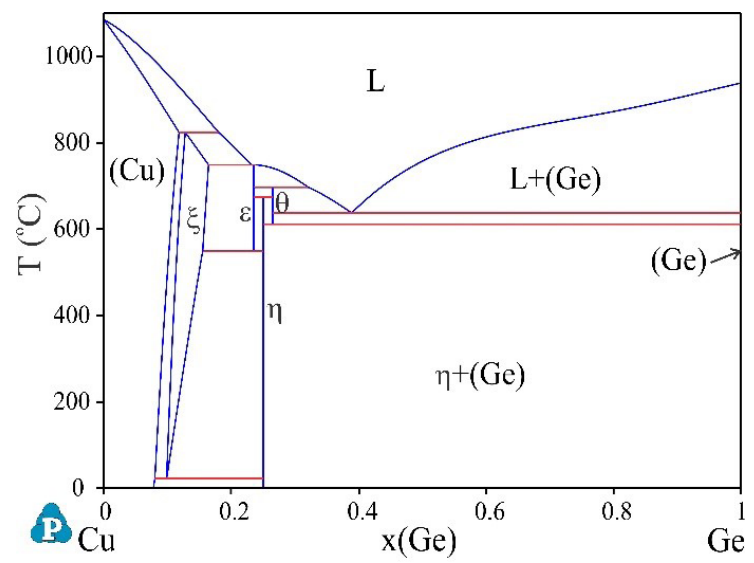

Figure 2. $\mathrm{Cu}-\mathrm{Ge}$ phase diagram calculated using thermodynamic data established by Wang et al. ${ }^{14}$. about 1 mass $\%$ and total mass of samples was about $4 \mathrm{~g}$. The samples were then divided into three groups.

One group of the samples (12 in total) were used for DTA tests by using Shimadzu DTG-60H thermal analyzer. Alumina crucibles were used and tests were performed under flowing argon atmosphere (produced by MESSER). The reference material was an empty alumina crucible. The samples weighing between 20 and $30 \mathrm{mg}$ were investigated at a heating rate of $5{ }^{\circ} \mathrm{C} / \mathrm{min}$ with three cycles of heating and cooling. The sample masses and heating rates were determined by analysis of one sample at different testing conditions. The sample was analyzed under heating rates of 5,10 and $15^{\circ} \mathrm{C} / \mathrm{min}$. It was found that the DTA curve obtained at the heating rate of $5^{\circ} \mathrm{C} / \mathrm{min}$ has slightly more pronounced peaks than the other two. Different masses of the same sample were then analyzed at the heating of $5^{\circ} \mathrm{C} / \mathrm{min}$ and the sample mass in range $20-30 \mathrm{mg}$ produced the most pronounced peaks. These sample mass and heating rates were adopted for analysis of all other samples. The liquidus temperatures were evaluated from the peak maximum and the temperatures of the invariant reactions were determined

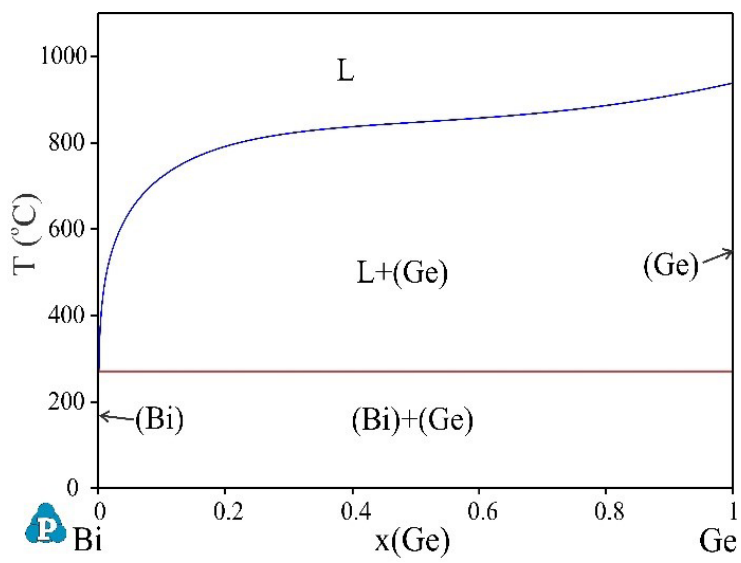

Figure 3. Bi-Ge phase diagram calculated using thermodynamic data established by Chevalier ${ }^{15}$.

Table 1. Crystal structure data for the solid phases in the $\mathrm{Bi}-\mathrm{Cu}-\mathrm{Ge}$ system.

\begin{tabular}{|c|c|c|c|c|c|c|}
\hline Phase & Temperature ${ }^{\circ} \mathrm{C}$ & Composition range & Space group & $\begin{array}{c}\text { Pearson's } \\
\text { symbol }\end{array}$ & Lattice parameters $\AA$ & Ref \\
\hline \multirow{2}{*}{ (Bi) } & \multirow{2}{*}{$<271.4$} & \multirow{2}{*}{100 at. $\% \mathrm{Bi}$} & \multirow{2}{*}{$R \overline{3} m$} & \multirow{2}{*}{$h R 2$} & $a=b=4.5461$ & \multirow{2}{*}{16} \\
\hline & & & & & $\mathrm{c}=11.8615$ & \\
\hline$(\mathrm{Cu})$ & $<1084$ & $88.3-100$ at. $\% \mathrm{Cu}$ & $F m \overline{3} m$ & $c F 4$ & $a=b=c=3.6573$ & 17 \\
\hline$(\mathrm{Ge})$ & $<938.2$ & 100 at. $\% \mathrm{Ge}$ & $F d \overline{3} m$ & $c F 8$ & $a=b=c=5.65675$ & 18 \\
\hline \multirow{2}{*}{$\xi$} & \multirow{2}{*}{$23.5-824.2$} & \multirow{2}{*}{83.5 to the 90.2 at. $\% \mathrm{Cu}$} & \multirow{2}{*}{$P 6_{3} / m m c$} & \multirow{2}{*}{$h P 2$} & $a=b=2.612$ & \multirow{2}{*}{19} \\
\hline & & & & & $c=4.231$ & \\
\hline \multirow{2}{*}{$\varepsilon$} & \multirow{2}{*}{$549.3-749$} & 76.5 at $\% \mathrm{Cu}$ & \multirow{2}{*}{$P 6_{3} / m m c$} & \multirow[b]{2}{*}{$\cdots$} & $a=b=4.169$ & \multirow{2}{*}{20} \\
\hline & & 23.5 at. $\% \mathrm{Ge}$ & & & $c=7.499$ & \\
\hline \multirow{3}{*}{$\eta$} & \multirow{3}{*}{$<674.5$} & 75 at. $\% \mathrm{Cu}$ & \multirow{3}{*}{ Pmnm } & \multirow{3}{*}{$o P 8$} & $a=5.29$ & \multirow{3}{*}{21} \\
\hline & & 25 at. $\% \mathrm{Ge}$ & & & $b=4.20$ & \\
\hline & & & & & $c=4.55$ & \\
\hline \multirow{2}{*}{$\theta$} & \multirow{2}{*}{$611.6-697.3$} & 73.5 at. $\% \mathrm{Cu}$ & \multirow[b]{2}{*}{$F m \overline{3} m$} & \multirow{2}{*}{$c I 2$} & \multirow{2}{*}{$a=b=c=5.906$} & \multirow{2}{*}{22} \\
\hline & & 26.5 at. $\% \mathrm{Ge}$ & & & & \\
\hline
\end{tabular}


from the real onset of the corresponding peaks. Based on the repeated heating measurements the overall uncertainty of the determined phase transformation temperatures was estimated to be $\pm 1{ }^{\circ} \mathrm{C}$.

The second group of the samples was used to study phase equilibria at $600^{\circ} \mathrm{C}$ and the third for phase equilibria at $400{ }^{\circ} \mathrm{C}$. Samples for investigation of isothermal sections at 600 and $400{ }^{\circ} \mathrm{C}$ were sealed in evacuated quartz tubes and then heated to a temperature that is $50^{\circ} \mathrm{C}$ higher than the melting temperature of $\mathrm{Ge}$. The alloy samples were then cooled down to $600\left(2^{\text {nd }}\right.$ series $)$ and $400{ }^{\circ} \mathrm{C}\left(3^{\text {rd }}\right.$ series $)$ at the cooling rate of $5^{\circ} \mathrm{Cmin}^{-1}$. The samples were kept at 600 and $400{ }^{\circ} \mathrm{C}$ for five weeks and then quenched in the water and ice mixture to preserve desired equilibria at 600 and $400{ }^{\circ} \mathrm{C}$. Those samples were prepared and used for SEM-EDS and XRD analysis.

The compositions of the alloy samples were determined using a JEOL JSM-6460 scanning electron microscope (SEM) which was equipped with an EDS system (Oxford Instruments $\mathrm{X}$-act). The samples for SEM-EDS analysis were first ground using sand paper, polished with diamond paste, and then cleaned in an ultrasonic bath. The overall compositions of the annealed samples were determined by mapping the entire polished surfaces of the samples. By contrast, the compositions of the observed coexisting phases were determined examining the surface of the same phase at different parts of the sample (at least five different positions of the same phase were examined per phase). The chemical compositions of the phases determined in this study represented the mean values based on at least five individual analyses.
Powder XRD data for the phase analysis of the alloy samples were recorded with a D2 PHASER (Bruker, Karlsruhe, Germany) powder diffractometer equipped with a dynamic scintillation detector and ceramic X-ray $\mathrm{Cu}$ tube (KFL-Cu-2K) in the $2 \theta$ range from $10^{\circ}$ to $75^{\circ}$ with a step size of $0.02^{\circ}$. Before the XRD analysis, the selected samples were first powdered using ball mill (YKT-04 machine) and the powders obtained were then placed in special holders and pressed to obtain compact samples. The recorded XRD patterns were subsequently analyzed using TOPAS 4.2 software and the International Centre for Diffraction Data (ICDD) Powder Diffraction Files (PDF2) database (2013). The lattice parameters were determined using TOPAS software and by performing full Rietveld refinement.

Calculations of the phase diagrams (binaries and ternary sections) as well as solidification paths (equilibrium and Scheil simulations) were performed using Pandat software and a thermodynamic dataset compiled from literature data ${ }^{13-}$ ${ }^{15}$ without using any ternary paramenters.

\section{Results and Discussion}

The six ternary samples annealed at $600{ }^{\circ} \mathrm{C}$ for five weeks and their microstructures were characterized using SEM-EDS and XRD, which results are presented in Table 2. Composition of the each sample was determined by EDS mapping of the entire sample's polished surface. Compositions of co-existing phases were determined by examining the surface of the same phase at different regions of the sample (at least five different positions of the same phase were examined per phase). Given that the compositions of $\varepsilon, \eta$

Table 2. Combined results of SEM-EDS and XRD analyzes of the selected Bi-Cu-Ge alloys annealed at $\mathrm{T}=600{ }^{\circ} \mathrm{C}$.

\begin{tabular}{|c|c|c|c|c|c|c|c|c|}
\hline \multirow{3}{*}{ No. } & \multirow{2}{*}{\multicolumn{2}{|c|}{$\frac{\text { Composition of samples }}{\text { (at. \%) }}$}} & \multicolumn{2}{|c|}{ Determined phases } & \multicolumn{3}{|c|}{ Compositions of phases (at.\%) } & \multirow{3}{*}{$\begin{array}{l}\text { Lattice parameters } \\
\qquad(\AA)\end{array}$} \\
\hline & & & \multirow{2}{*}{ EDS } & \multirow{2}{*}{ XRD } & \multirow{2}{*}{$\mathrm{Bi}$} & \multirow{2}{*}{$\mathrm{Cu}$} & \multirow{2}{*}{$\mathrm{Ge}$} & \\
\hline & Nominal & EDS & & & & & & \\
\hline \multirow{3}{*}{1} & $90 \mathrm{Bi}$ & $89.1 \mathrm{Bi}$ & $\mathrm{L}$ & - & $93.52 \pm 0.5$ & $1.58 \pm 0.2$ & $4.90 \pm 0.1$ & - \\
\hline & $1 \mathrm{Cu}$ & $0.9 \mathrm{Cu}$ & $(\mathrm{Ge})$ & $(\mathrm{Ge})$ & $0.01 \pm 0.3$ & $0.19 \pm 0.1$ & $99.80 \pm 0.7$ & $a=b=c=5.6531$ \\
\hline & $9 \mathrm{Ge}$ & $10.0 \mathrm{Ge}$ & & & & & & \\
\hline \multirow{3}{*}{2} & $37 \mathrm{Bi}$ & $36.8 \mathrm{Bi}$ & $\mathrm{L}$ & - & $93.88 \pm 0.2$ & $2.29 \pm 0.8$ & $3.83 \pm 0.3$ & - \\
\hline & $25 \mathrm{Cu}$ & $25.6 \mathrm{Cu}$ & $(\mathrm{Ge})$ & $(\mathrm{Ge})$ & $0.03 \pm 0.3$ & $0.08 \pm 0.3$ & $99.89 \pm 0.4$ & $a=b=c=5.6547$ \\
\hline & $38 \mathrm{Ge}$ & $37.6 \mathrm{Ge}$ & $\eta$ & $\eta$ & $0.09 \pm 0.6$ & $75.73 \pm 0.1$ & $24.18 \pm 0.6$ & $\begin{array}{c}\mathrm{a}=5.2902, \\
\mathrm{~b}=4.2003, \mathrm{c}=4.5487\end{array}$ \\
\hline \multirow{3}{*}{3} & $38 \mathrm{Bi}$ & $38.2 \mathrm{Bi}$ & $\mathrm{L}$ & - & $93.18 \pm 0.5$ & $3.28 \pm 0.2$ & $3.54 \pm 0.2$ & - \\
\hline & $35 \mathrm{Cu}$ & $33.5 \mathrm{Cu}$ & $(\mathrm{Ge})$ & $(\mathrm{Ge})$ & $0.05 \pm 0.5$ & $0.77 \pm 0.5$ & $99.18 \pm 0.1$ & $a=b=c=5.6552$ \\
\hline & $27 \mathrm{Ge}$ & $28.3 \mathrm{Ge}$ & $\eta$ & $\eta$ & $0.07 \pm 0.5$ & $73.82 \pm 0.4$ & $26.11 \pm 0.5$ & $\begin{array}{c}\mathrm{a}=5.2892, \\
\mathrm{~b}=4.2123, \mathrm{c}=4.5531\end{array}$ \\
\hline \multirow{3}{*}{4} & $37 \mathrm{Bi}$ & $36.8 \mathrm{Bi}$ & $\mathrm{L}$ & - & $93.52 \pm 0.1$ & $5.72 \pm 0.7$ & $0.76 \pm 0.4$ & - \\
\hline & $50 \mathrm{Cu}$ & $51.0 \mathrm{Cu}$ & $\varepsilon$ & $\varepsilon$ & $0.55 \pm 0.7$ & $76.47 \pm 0.5$ & $22.98 \pm 0.3$ & $\begin{array}{c}\mathrm{a}=\mathrm{b}=4.1673, \\
\mathrm{c}=7.5003\end{array}$ \\
\hline & $13 \mathrm{Ge}$ & $12.2 \mathrm{Ge}$ & $\xi$ & $\xi$ & $0.37 \pm 0.2$ & $83.40 \pm 0.2$ & $16.23 \pm 0.1$ & $\begin{array}{c}a=b=2.6022, \\
c=4.2352\end{array}$ \\
\hline \multirow{3}{*}{5} & $32 \mathrm{Bi}$ & $32.2 \mathrm{Bi}$ & $\mathrm{L}$ & - & $91.68 \pm 0.4$ & $8.27 \pm 0.1$ & $0.05 \pm 0.3$ & - \\
\hline & $64 \mathrm{Cu}$ & $63.9 \mathrm{Cu}$ & $(\mathrm{Cu})$ & $(\mathrm{Cu})$ & $0.74 \pm 0.3$ & $93.30 \pm 0.2$ & $5.96 \pm 0.6$ & $a=b=c=3.6652$ \\
\hline & $4 \mathrm{Ge}$ & $3.9 \mathrm{Ge}$ & & & & & & \\
\hline \multirow{3}{*}{6} & $10 \mathrm{Bi}$ & $10.1 \mathrm{Bi}$ & $\mathrm{L}$ & - & $90.95 \pm 0.7$ & $8.63 \pm 0.5$ & $0.42 \pm 0.2$ & - \\
\hline & $86 \mathrm{Cu}$ & $86.3 \mathrm{Cu}$ & $(\mathrm{Cu})$ & $(\mathrm{Cu})$ & $0.56 \pm 0.2$ & $96.33 \pm 0.4$ & $3.11 \pm 0.1$ & $a=b=c=3.6611$ \\
\hline & $4 \mathrm{Ge}$ & $3.6 \mathrm{Ge}$ & & & & & & \\
\hline
\end{tabular}


and $\theta$ phases are close to each other, XRD analysis was used for identification of the present phases.

With analysis of six ternary alloy samples, four different phase regions are detected. In the microstructure of sample $1, \mathrm{~L}$ and $(\mathrm{Ge})$ phase were detected. Presence of the same three phases $\mathrm{L},(\mathrm{Ge})$ and intermetallic compound $\eta$ was confirmed in samples 2 and 3. Three phases L, $\varepsilon$ and $\xi$ were detected in sample 4 whereas the same two phases $\mathrm{L}$ and $(\mathrm{Cu})$ were detected in samples 5 and 6 . Identification of the phases detected by XRD was accomplished using literature information from references ${ }^{17-21}$. Microstructures and XRD patterns from two of the samples investigated in the present work (samples 1 and 4) are presented in Figure 4 as an illustration.

Within microstructure of sample 1, the observed gray phase was found to be L phase while dark phase is (Ge) solid solution. Figure 4b) presents microstructure of sample 4 in which three phases are visible, L phase that appears as a gray phase, $\varepsilon$ phase as a dark phase with oval shape and $\xi$ phase as dark dendrite phase.

The calculated isothermal section and the EDS results given in Table 2 are presented together on Figure 5. Ten phase regions are clearly noted at $600{ }^{\circ} \mathrm{C}$ : (i) one is the $\mathrm{L}$ single phase region at the $\mathrm{Bi}$-rich corner; five are two-phase regions $\mathrm{L}+(\mathrm{Ge}), \mathrm{L}+\eta, \mathrm{L}+\varepsilon, \mathrm{L}+\xi$ and $\mathrm{L}+(\mathrm{Cu})$; four are threephase regions $\mathrm{L}+\eta+(\mathrm{Ge}), \mathrm{L}+\varepsilon+\eta, \mathrm{L}+\varepsilon+\xi$ and $\mathrm{L}+\xi+(\mathrm{Cu})$. From the ten calculated phase regions, the existence of four was experimentally confirmed, which are: $\mathrm{L}+(\mathrm{Ge})$ in sample $1, \mathrm{~L}+\eta+(\mathrm{Ge})$ in samples 2 and $3, \mathrm{~L}+\varepsilon+\xi$ in sample 4 , and $\mathrm{L}+(\mathrm{Cu})$ in samples 5 and 6 . When compared with one another, it is clear that the experimentally determined compositions of phases are very close to the calculated compositions of phases. Hence, it can be concluded that the experiments support the calculated isothermal section at $600{ }^{\circ} \mathrm{C}$ quite well.

Six ternary alloy samples marked with numbers from 7 to 12 were used for studying phase equilibria at $400{ }^{\circ} \mathrm{C}$. The samples were annealed at $400{ }^{\circ} \mathrm{C}$ for five weeks and then tested with SEM-EDS and XRD. Results of the tests are given in Table 3. Compositions of the samples and compositions of co-existing phases were determined by the same procedure as applied for the samples annealed at $600{ }^{\circ} \mathrm{C}$.

Analysis of the six annealed alloy samples has confirmed existence of three different phase regions. In the microstructures
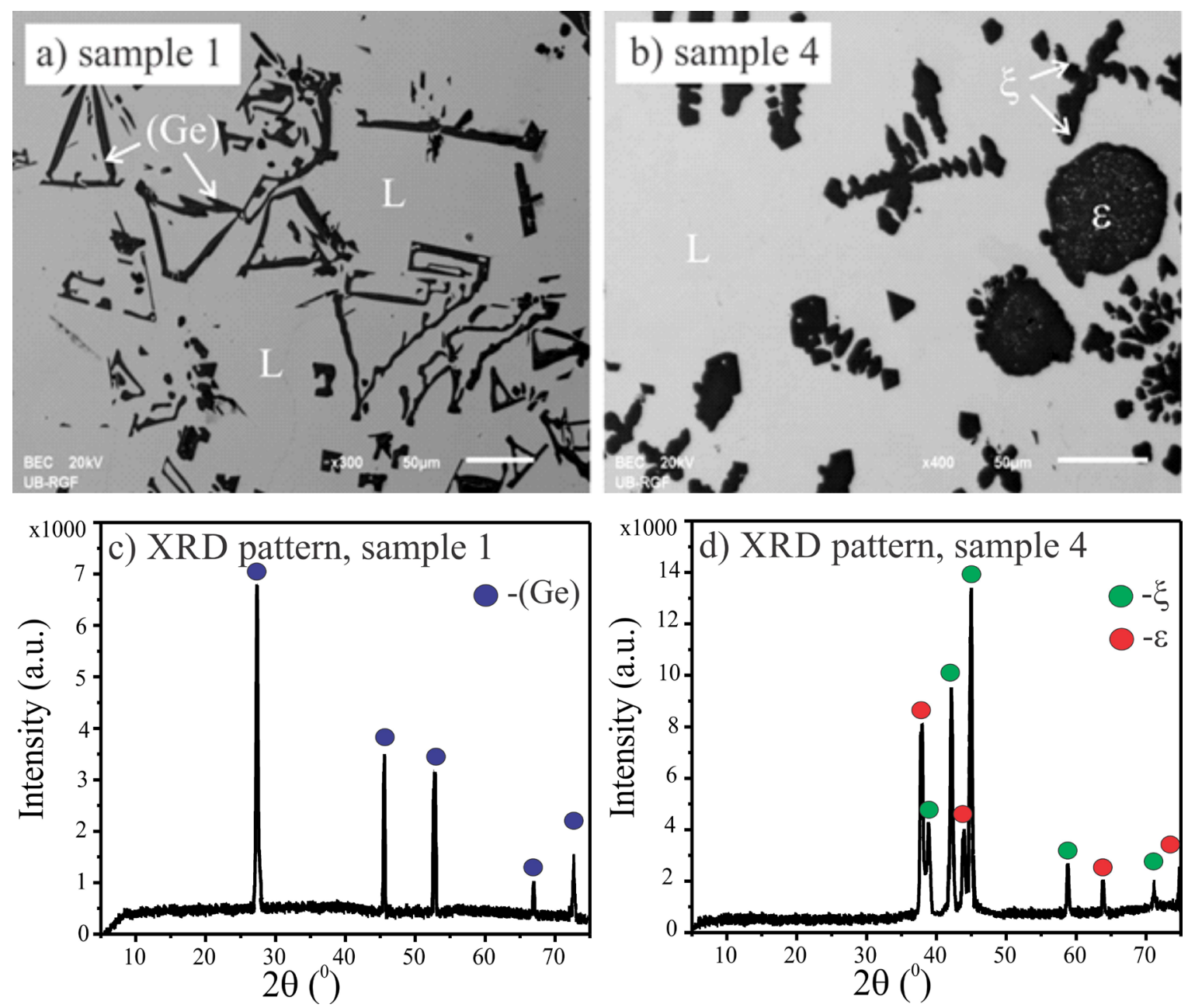

Figure 4. SEM-BSEI micrographs and XRD patterns of samples 1 and 4 annealed at $600{ }^{\circ} \mathrm{C}$ for five weeks. 
of samples 7, 8 and 9 three phases were detected, which include $\mathrm{L},(\mathrm{Ge})$ phase and intermetallic compound $\eta$. Another three-phase region was confirmed by the microstructural characterization of sample 10, where three phases L, $\eta$ and $\xi$ were detected. The same two phases $\mathrm{L}$ and $(\mathrm{Cu})$ were detected in samples 11 and 12. Identification of the phases detected by XRD was carried out using literature information

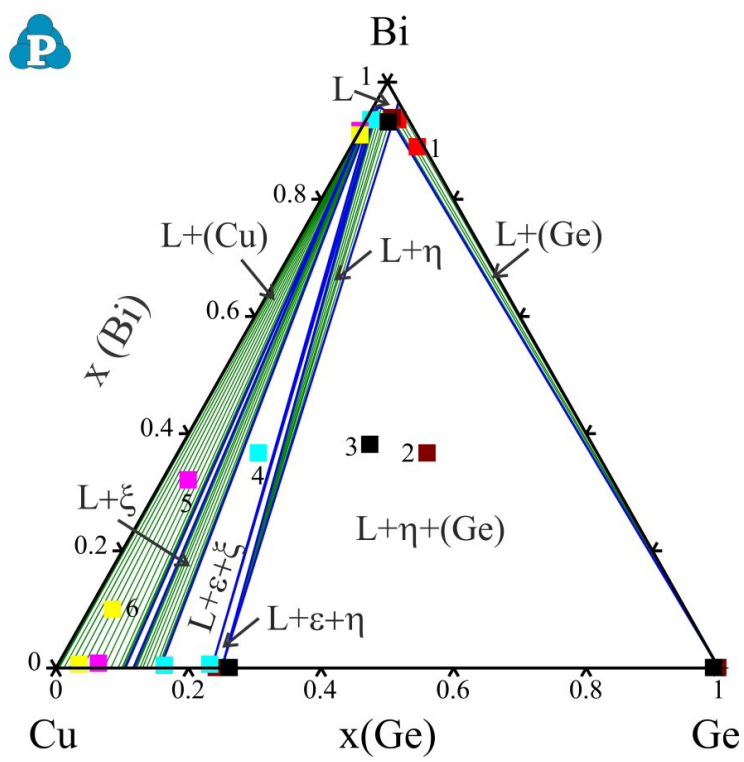

Figure 5. Calculated $\mathrm{Bi}-\mathrm{Cu}-\mathrm{Ge}$ isothermal section at $600{ }^{\circ} \mathrm{C}$ compared with EDS results given in Table 2. from references ${ }^{17-19,21}$. The EDS results (Table 3) show that L phase detected in all of the samples is rich with bismuth and that it can dissolve small amount of the other two elements. Solid solution $(\mathrm{Ge})$, detected in samples 7, 8 and 9 is rich with germanium $(98.08,98.18$ and 98.83 at. \%, respectively) and the rest is bismuth and copper. Intermetallic compound $\eta$ is a line compound with composition 75 at. $\% \mathrm{Cu}$ and 25 at. $\%$ Ge. However, in our study, the $\eta$ phase was detected with a slightly different composition in samples annealed at $400{ }^{\circ} \mathrm{C}$, consisting of 72.92 to 75.79 at. $\%$ of $\mathrm{Cu}$ and 24.15 to 26.54 at. $\% \mathrm{Ge}$, while the rest is a small amount of bismuth. According to the literature, $\xi$ phase contains from 83.5 to 90.2 at. $\%$ of $\mathrm{Cu}$ and the rest is germanium, which is in agreement with composition of the phase (85.41 at. \% of $\mathrm{Cu})$ detected in sample 10. In samples 11 and $12,(\mathrm{Cu})$ solid solution was identified with composition 94.23 - 98.20 at. \% of $\mathrm{Cu}$ which is in agreement with a literature composition 88.3-100 at. $\% \mathrm{Cu}$.

Microstructures and XRD patterns from two of the samples investigated in the present work (samples 8 and 11) are presented on Figure 6 as an illustration. In the microstructure of sample 8, the observed gray phase was identified as L phase, the dark phase with a needle-shaped was found to be $(\mathrm{Ge})$ solid solution while the other dark phase is the intermetallic compound $\eta$. Figure $6 \mathrm{~b}$ presents the microstructure of sample 11 in which two phases are visible, $\mathrm{L}$ phase that appears as a gray phase and $(\mathrm{Cu})$ phase as a dark oval phase.

The collected experimental results given in Table 3 were compared with the calculated isothermal section at 400 ${ }^{\circ} \mathrm{C}$ and presented together in Figure 7. On the calculated

Table 3. Combined results of SEM-EDS and XRD analyzes of the selected Bi-Cu-Ge alloys annealed at $\mathrm{T}=400{ }^{\circ} \mathrm{C}$.

\begin{tabular}{|c|c|c|c|c|c|c|c|c|}
\hline \multirow{3}{*}{ No. } & \multirow{2}{*}{\multicolumn{2}{|c|}{$\frac{\text { Composition of samples }}{\text { (at. \%) }}$}} & \multicolumn{2}{|c|}{ Determined phases } & \multicolumn{3}{|c|}{ Compositions of phases (at.\%) } & \multirow{3}{*}{$\begin{array}{l}\text { Lattice parameters } \\
\qquad(\AA)\end{array}$} \\
\hline & & & \multirow{2}{*}{ EDS } & \multirow{2}{*}{ XRD } & \multirow{2}{*}{$\mathrm{Bi}$} & \multirow{2}{*}{$\mathrm{Cu}$} & \multirow{2}{*}{$\mathrm{Ge}$} & \\
\hline & Nominal & EDS & & & & & & \\
\hline \multirow{3}{*}{7} & $50 \mathrm{Bi}$ & $47.0 \mathrm{Bi}$ & $\mathrm{L}$ & - & $99.18 \pm 0.1$ & $0.81 \pm 0.1$ & $0.01 \pm 0.4$ & - \\
\hline & $10 \mathrm{Cu}$ & $11.4 \mathrm{Cu}$ & $(\mathrm{Ge})$ & $(\mathrm{Ge})$ & $0.20 \pm 0.5$ & $1.62 \pm 0.4$ & $98.18 \pm 0.5$ & $a=b=c=5.6579$ \\
\hline & $40 \mathrm{Ge}$ & $41.6 \mathrm{Ge}$ & $\eta$ & $\eta$ & $0.34 \pm 0.4$ & $73.53 \pm 0.3$ & $26.13 \pm 0.1$ & $\begin{array}{c}a=5.2911, \\
b=4.2087, c=4.5541\end{array}$ \\
\hline \multirow{3}{*}{8} & $22 \mathrm{Bi}$ & $22.5 \mathrm{Bi}$ & $\mathrm{L}$ & - & $99.82 \pm 0.3$ & $0.15 \pm 0.4$ & $0.03 \pm 0.2$ & - \\
\hline & $33 \mathrm{Cu}$ & $32.8 \mathrm{Cu}$ & $(\mathrm{Ge})$ & $(\mathrm{Ge})$ & $0.01 \pm 0.7$ & $1.91 \pm 0.5$ & $98.08 \pm 0.6$ & $a=b=c=5.6558$ \\
\hline & $45 \mathrm{Ge}$ & $44.7 \mathrm{Ge}$ & $\eta$ & $\eta$ & $0.03 \pm 0.4$ & $75.79 \pm 0.7$ & $24.18 \pm 0.7$ & $\begin{array}{c}a=5.2972, \\
b=4.2152, c=4.5598\end{array}$ \\
\hline \multirow{3}{*}{9} & $37 \mathrm{Bi}$ & $36.9 \mathrm{Bi}$ & $\mathrm{L}$ & - & $99.01 \pm 0.2$ & $0.68 \pm 0.1$ & $0.31 \pm 0.6$ & - \\
\hline & $40 \mathrm{Cu}$ & $40.2 \mathrm{Cu}$ & $(\mathrm{Ge})$ & $(\mathrm{Ge})$ & $0.12 \pm 0.5$ & $1.05 \pm 0.3$ & $98.83 \pm 0.4$ & $a=b=c=5.6560$ \\
\hline & $23 \mathrm{Ge}$ & $22.9 \mathrm{Ge}$ & $\eta$ & $\eta$ & $0.54 \pm 0.6$ & $72.92 \pm 0.7$ & $26.54 \pm 0.4$ & $\begin{array}{c}a=5.2978, \\
b=4.2155, c=4.5613\end{array}$ \\
\hline \multirow{3}{*}{10} & $30 \mathrm{Bi}$ & $30.7 \mathrm{Bi}$ & $\mathrm{L}$ & - & $98.18 \pm 0.1$ & $1.50 \pm 0.2$ & $0.32 \pm 0.3$ & - \\
\hline & $55 \mathrm{Cu}$ & $55.7 \mathrm{Cu}$ & $\eta$ & $\eta$ & $0.13 \pm 0.3$ & $75.72 \pm 0.6$ & $24.15 \pm 0.2$ & $\begin{array}{c}a=5.2968, \\
b=4.2052, c=4.5573\end{array}$ \\
\hline & $15 \mathrm{Ge}$ & $13.6 \mathrm{Ge}$ & $\xi$ & $\xi$ & $0.92 \pm 0.7$ & $85.41 \pm 0.8$ & $13.67 \pm 0.1$ & $\begin{array}{c}a=b=2.6125, \\
c=4.2392\end{array}$ \\
\hline \multirow{3}{*}{11} & $32 \mathrm{Bi}$ & $32.3 \mathrm{Bi}$ & $\mathrm{L}$ & - & $98.01 \pm 0.1$ & $1.81 \pm 0.1$ & $0.18 \pm 0.5$ & - \\
\hline & $65 \mathrm{Cu}$ & $65.2 \mathrm{Cu}$ & $(\mathrm{Cu})$ & $(\mathrm{Cu})$ & $0.15 \pm 0.2$ & $94.23 \pm 0.2$ & $5.62 \pm 0.7$ & $a=b=c=3.6631$ \\
\hline & $3 \mathrm{Ge}$ & $2.5 \mathrm{Ge}$ & & & & & & \\
\hline \multirow{3}{*}{12} & $63 \mathrm{Bi}$ & $63.3 \mathrm{Bi}$ & $\mathrm{L}$ & - & $98.81 \pm 0.5$ & $0.67 \pm 0.5$ & $0.52 \pm 0.2$ & - \\
\hline & $35 \mathrm{Cu}$ & $35.2 \mathrm{Cu}$ & $(\mathrm{Cu})$ & $(\mathrm{Cu})$ & $0.37 \pm 0.1$ & $98.20 \pm 0.2$ & $1.43 \pm 0.3$ & $a=b=c=3.6598$ \\
\hline & $2 \mathrm{Ge}$ & $1.5 \mathrm{Ge}$ & & & & & & \\
\hline
\end{tabular}



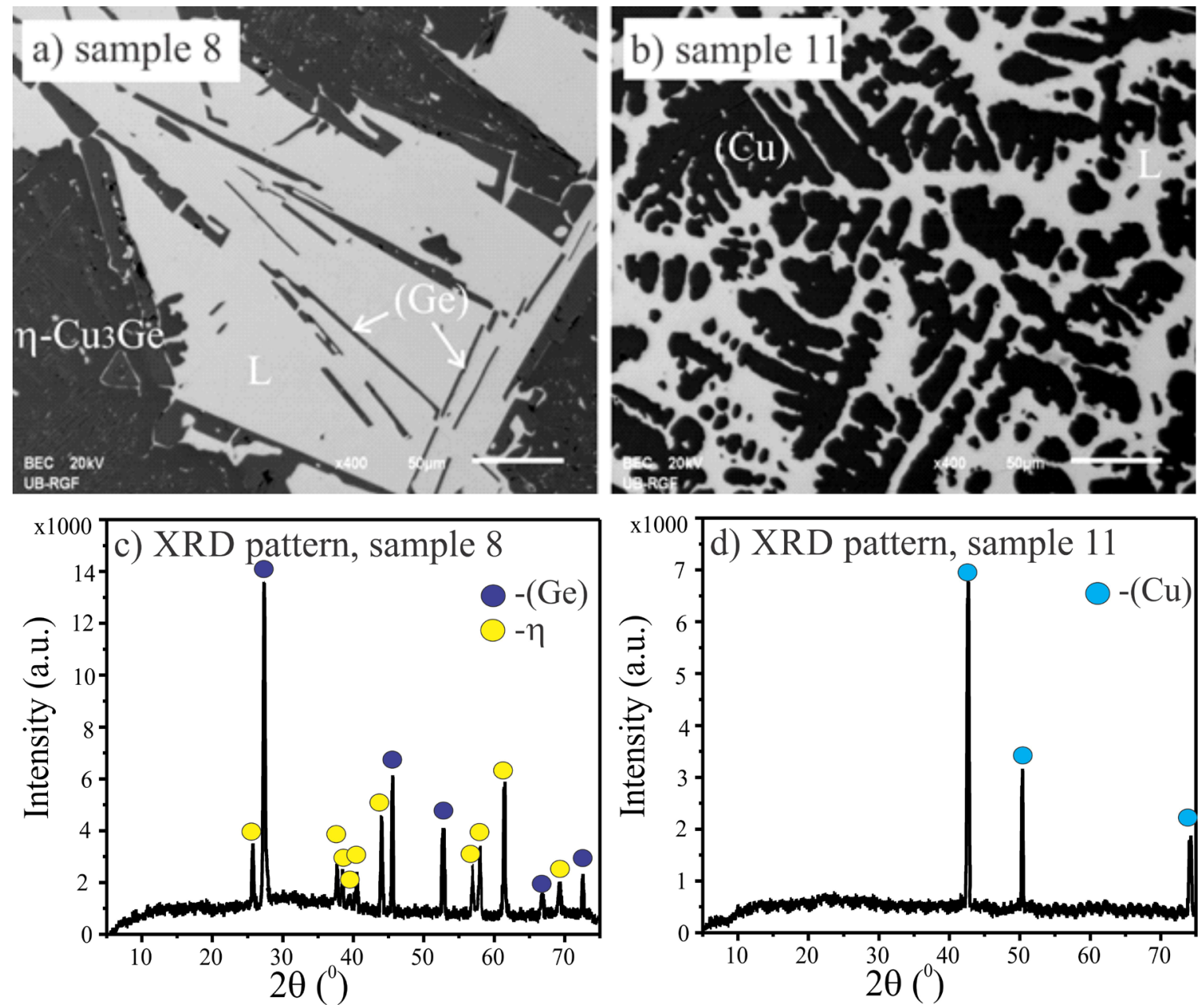

Figure 6. SEM-BSEI micrographs and XRD patterns of samples 8 and 11 annealed at $400{ }^{\circ} \mathrm{C}$ for five weeks.

isothermal section (Figure 7) six phase regions are visible. Three are two-phase regions $\mathrm{L}+\eta, \mathrm{L}+\xi$ and $\mathrm{L}+(\mathrm{Cu})$ and three are three-phase regions $\mathrm{L}+\eta+(\mathrm{Ge}), \mathrm{L}+\eta+\xi$ and $\mathrm{L}+\xi+(\mathrm{Cu})$. Out of the six calculated phase regions three were experimentally confirmed. Existence of $\mathrm{L}+\eta+(\mathrm{Ge})$ phase region was confirmed in samples 7,8 and $9, \mathrm{~L}+\eta+\xi$ in sample 10 and $\mathrm{L}+(\mathrm{Cu})$ in samples 11 and 12 . In this case also it is clear that the experimentally determined compositions of phases are close to the calculated compositions of phases. Therefore, it can be also concluded that the experiments support the calculated isothermal section at $400{ }^{\circ} \mathrm{C}$.

Twelve ternary as-cast samples were selected for DTA tests. The samples were placed in alumina crucibles and characteristic temperatures were recorded under protective flowing Ar atmosphere. Weights of the analyzed alloy samples were between 20 and $30 \mathrm{mg}$ and the reference material was an empty alumina crucible. Determination of phase transition temperatures was carried out according to recommendations from the literature ${ }^{23,24}$. The liquidus and temperatures of monovariant phase transitions were determined from peak maxima while the solidus temperatures and the temperatures of invariant reactions were determined

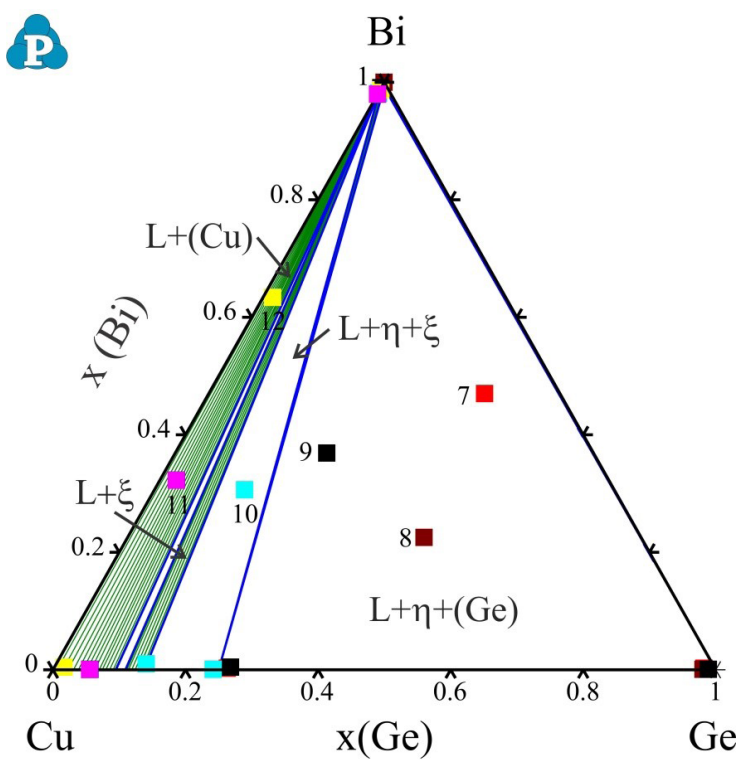

Figure 7. Calculated $\mathrm{Bi}-\mathrm{Cu}-\mathrm{Ge}$ isothermal section at $400{ }^{\circ} \mathrm{C}$ compared with the EDS results given in Table 3. 
Table 4. Phase transition temperatures of the studied alloys from the ternary Bi-Cu-Ge system determined by DTA at pressure $\mathrm{p}=0.1 \mathrm{MPa}$.

\begin{tabular}{|c|c|c|c|c|c|}
\hline \multirow[b]{2}{*}{ Number } & \multicolumn{2}{|c|}{ Composition (at. \%) } & \multicolumn{3}{|c|}{ Identified phase transition temperature in ${ }^{\circ} \mathrm{C}$} \\
\hline & nominal & EDS & $\begin{array}{c}\text { Ternary eutectic } \\
\text { reaction }\end{array}$ & Ternary transition reaction & $\begin{array}{c}\text { Binodal or } \\
\text { Liquidus }\end{array}$ \\
\hline \multicolumn{6}{|c|}{ Vertical section Bi-CuGe } \\
\hline 13 & $\mathrm{Bi}_{20} \mathrm{Cu}_{40} \mathrm{Ge}_{40}$ & $\mathrm{Bi}_{20.15} \mathrm{Cu}_{39.18} \mathrm{Ge}_{40.67}$ & $279 / 613 / 636$ & 701 & 849 \\
\hline 14 & $\mathrm{Bi}_{30} \mathrm{Cu}_{35} \mathrm{Ge}_{35}$ & $\mathrm{Bi}_{29.11} \mathrm{Cu}_{35.48} \mathrm{Ge}_{35.41}$ & $269 / 610 / 629$ & - & 933 \\
\hline 15 & $\mathrm{Bi}_{50} \mathrm{Cu}_{25} \mathrm{Ge}_{25}$ & $\mathrm{Bi}_{49.81} \mathrm{Cu}_{25.13} \mathrm{Ge}_{25.06}$ & $275 / 610 / 634$ & - & 980 \\
\hline 16 & $\mathrm{Bi}_{70} \mathrm{Cu}_{15} \mathrm{Ge}_{15}$ & $\mathrm{Bi}_{70.02} \mathrm{Cu}_{14.81} \mathrm{Ge}_{15.17}$ & $278 /-/ 622$ & - & 919 \\
\hline \multicolumn{6}{|c|}{ Vertical section $\mathrm{Cu}-\mathrm{BiGe}$} \\
\hline 17 & $\mathrm{Bi}_{45} \mathrm{Cu}_{10} \mathrm{Ge}_{45}$ & $\mathrm{Bi}_{45.01} \mathrm{Cu}_{9.81} \mathrm{Ge}_{45.18}$ & $278 / 614 / 627$ & - & 779 \\
\hline 18 & $\mathrm{Bi}_{35} \mathrm{Cu}_{30} \mathrm{Ge}_{35}$ & $\mathrm{Bi}_{35.52} \mathrm{Cu}_{29.61} \mathrm{Ge}_{34.87}$ & $279 / 614.87 / 634$ & - & 938 \\
\hline 19 & $\mathrm{Bi}_{27.5} \mathrm{Cu}_{45} \mathrm{Ge}_{27.5}$ & $\mathrm{Bi}_{27.43} \mathrm{Cu}_{44.87} \mathrm{Ge}_{27.70}$ & $277 / 613 / 629$ & - & 1036 \\
\hline 20 & $\mathrm{Bi}_{20} \mathrm{Cu}_{60} \mathrm{Ge}_{20}$ & $\mathrm{Bi}_{19.73} \mathrm{Cu}_{61.12} \mathrm{Ge}_{19.15}$ & $277 / 681$ & 727 & 1042 \\
\hline \multicolumn{6}{|c|}{ Vertical section $\mathrm{Ge}-\mathrm{BiCu}$} \\
\hline 21 & $\mathrm{Bi}_{45} \mathrm{Cu}_{45} \mathrm{Ge}_{10}$ & $\mathrm{Bi}_{45.08} \mathrm{Cu}_{44.87} \mathrm{Ge}_{10.05}$ & $278 / 549 / 724$ & 766 & 1129 \\
\hline 22 & $\mathrm{Bi}_{35} \mathrm{Cu}_{35} \mathrm{Ge}_{30}$ & $\mathrm{Bi}_{34.98} \mathrm{Cu}_{35.09} \mathrm{Ge}_{29.93}$ & $279 / 615 / 631$ & - & 1025 \\
\hline 23 & $\mathrm{Bi}_{20} \mathrm{Cu}_{20} \mathrm{Ge}_{60}$ & $\mathrm{Bi}_{19.35} \mathrm{Cu}_{20.87} \mathrm{Ge}_{59.78}$ & $280 / 616 / 632$ & 769 & - \\
\hline 24 & $\mathrm{Bi}_{5} \mathrm{Cu}_{5} \mathrm{Ge}_{90}$ & $\mathrm{Bi}_{4.35} \mathrm{Cu}_{4.91} \mathrm{Ge}_{90.74}$ & $278 / 615 / 628$ & 733 & 916 \\
\hline
\end{tabular}
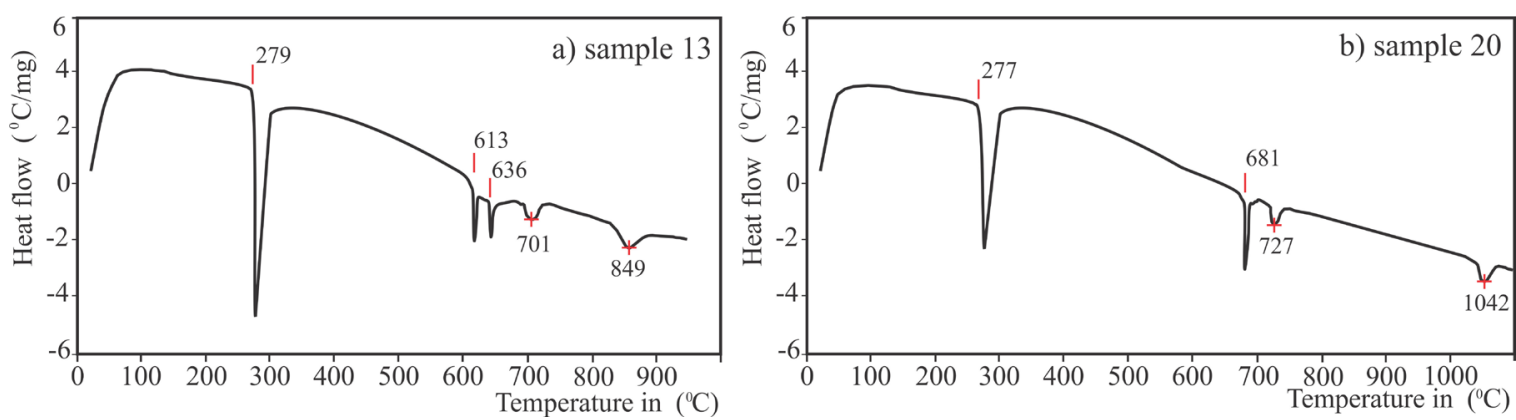

Figure 8. DTA heating curve of samples 13 and 20

from onset temperatures of the corresponding peaks. The determined temperatures from DTA heating curves for the 12 studied samples are summarized in Table 4. Some DTA heating curves are presented on Figure 8.

From the compiled DTA results in Table 4, it can be seen that for three of the studied samples five peaks were detected, four peaks were recorded for eight of the samples and three peaks for sample $\mathrm{Bi}_{70} \mathrm{Cu}_{15} \mathrm{Ge}_{15}$. It can be noticed that the first detected peak for each sample has similar temperature value, so it can be assumed that they are related to the same transformation. The last detected temperature for each sample correspond to its liquidus temperature, while the peaks in-between belong to ternary transition reactions. The experimentally determined temperatures from Table 4 are compared with calculated vertical sections. The calculated vertical sections: $\mathrm{Bi}-\mathrm{CuGe}, \mathrm{Cu}-\mathrm{BiGe}$ and $\mathrm{Ge}-\mathrm{BiCu}$ are presented in Figure 9.

Comparison of the results of calculations and experimental results given in Figure 9 depicts a fairly close agreement between them. Figure 9a presents the calculated vertical section $\mathrm{Bi}-\mathrm{CuGe}$ compared with the experimental results for samples 13-16 (Table 4). From the calculations it is clear that first detected temperature for all of the samples is related to the same transformation which is ascribed to a ternary eutectic reaction $\mathrm{L} \rightarrow(\mathrm{Ge})+(\mathrm{Bi})+\eta$. According to the calculations the reaction takes place at $271.07^{\circ} \mathrm{C}$, while the experimentally determined temperatures are in range of 269 to $279^{\circ} \mathrm{C}$, which are fairly close to the calculated value. The second detected temperature for samples 13,14 and 15 is related to $\theta \rightarrow \mathrm{L}+(\mathrm{Ge})+\eta$ reaction. The calculated temperature for this reaction is $611.64{ }^{\circ} \mathrm{C}$, whereas the experimental values are 610 to $614{ }^{\circ} \mathrm{C}$, which again are fairly close to each other. This transformation was not observed for sample 16 , although according to the calculations it should be. The third detected temperature for all of the samples is related to the $\mathrm{L} \rightarrow \mathrm{L}+(\mathrm{Ge})+\theta$ transition. Its calculated temperature is $623.05{ }^{\circ} \mathrm{C}$, while the experimentally determined ones are slightly higher $622,629,634$ and $636^{\circ} \mathrm{C}$. Sample $\mathrm{Bi}_{20.15} \mathrm{Cu}_{39.18} \mathrm{Ge}_{40.67}$ was also utilized to determine temperature of $\mathrm{L}^{\prime}+\mathrm{L} " \rightarrow \mathrm{L} '+\mathrm{L} "+(\mathrm{Ge})$ transformation at $701{ }^{\circ} \mathrm{C}$. The last temperature for all of the studied samples is associated with a binodal phase transition and all of the experimental temperatures agree well with the calculated ones.

Figure $9 \mathrm{~b}$ shows DTA results of 4 samples from the vertical section $\mathrm{Cu}-\mathrm{BiGe}$ (samples 17, 18, 19 and 20 in Table 4). Four transition temperatures were detected for the each studied 


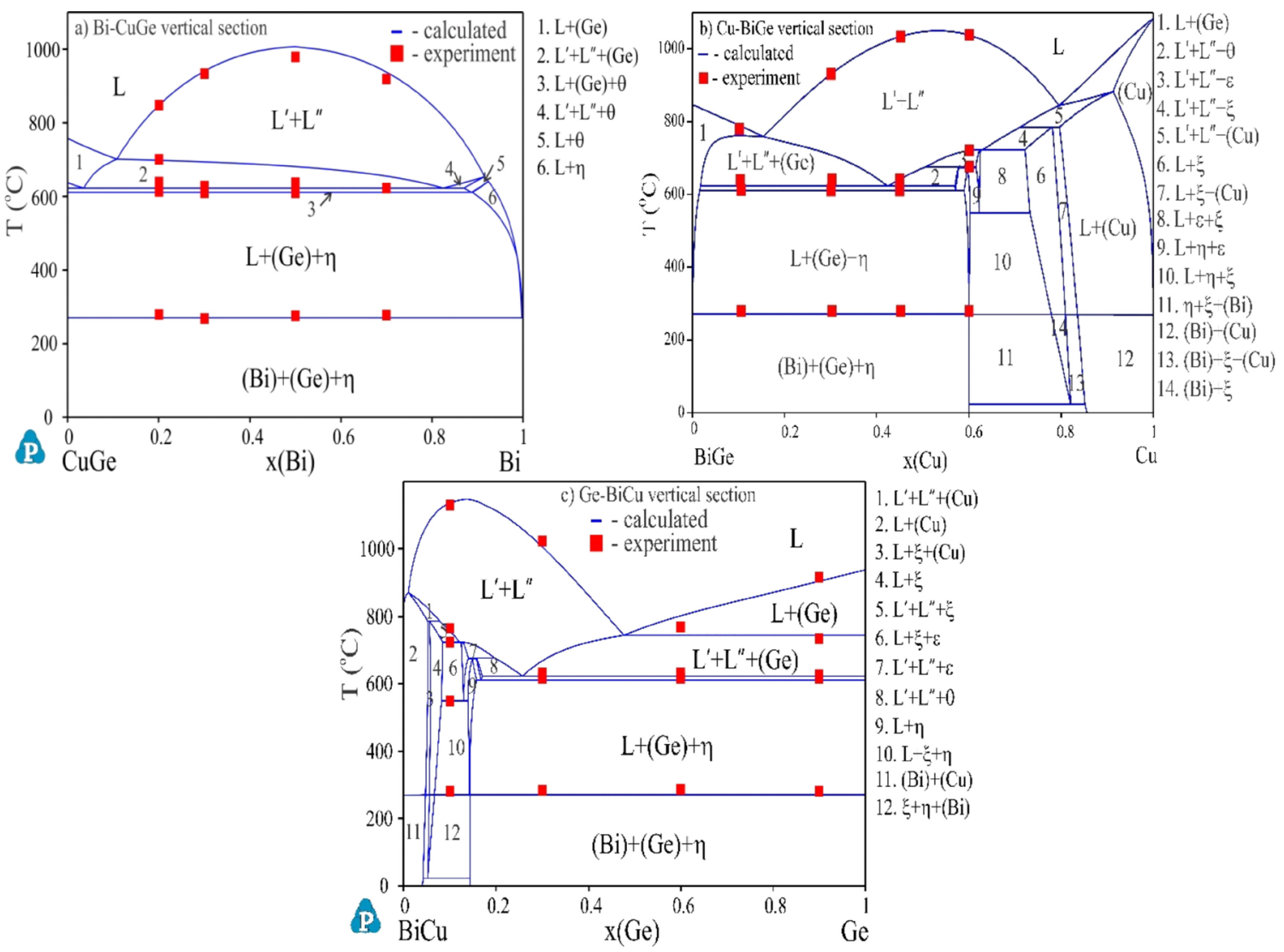

Figure 9. Calculated vertical sections of the ternary Bi-Cu-Ge system compared with DTA experimental results: a) Bi-CuGe, b) $\mathrm{Cu}-\mathrm{BiGe}$ and c) $\mathrm{Ge}-\mathrm{BiCu}$.

sample. By comparing the DTA results and the calculated vertical section Figure 9b, it can be noticed that the all four temperatures detected for samples 17,18 and 19 correspond to the same phase transformation. The first temperatures are related to a ternary eutectic reaction $\mathrm{L} \rightarrow(\mathrm{Ge})+(\mathrm{Bi})+\eta$ which according to calculations takes place at $271.07{ }^{\circ} \mathrm{C}$. The experimentally detected temperatures for this reaction are 278,279 and $277^{\circ} \mathrm{C}$ which are fairly close to the calculated one. The second detected temperatures $\left(614,615\right.$ and $\left.613^{\circ} \mathrm{C}\right)$ are related to a ternary phase transformation $\theta \rightarrow \mathrm{L}+(\mathrm{Ge})+\eta$ predicted by calculations at $611.64^{\circ} \mathrm{C}$. The third temperatures for samples 17,18 and 19 are 627,634 and $629^{\circ} \mathrm{C}$, respectively. These temperatures are related to the $\mathrm{L} \rightarrow \mathrm{L}+(\mathrm{Ge})+\theta$ phase transformation with the calculated temperature at $623.05^{\circ} \mathrm{C}$. The last detected temperatures for the studied samples from $\mathrm{Cu}-\mathrm{BiGe}$ vertical section are liquidus and binodal phase transition temperatures. Sample 20, although being from the same vertical section, exhibits different phase transformations than samples 17 to 19 . The first temperature is related to a transformation of $\mathrm{L}+\eta \rightarrow \xi+(\mathrm{Bi})$, the second to the $\mathrm{L}+\varepsilon \rightarrow \mathrm{L}+\xi$, the third to the $\mathrm{L}^{\prime}+\mathrm{L} " \rightarrow \mathrm{L}$ ' $+\mathrm{L}$ " $+\theta$ and the last one to a binodal phase transition temperature.

Four samples from vertical section $\mathrm{Ge}-\mathrm{BiCu}$ that were tested are marked with numbers 21 to 24 in Table 4. Five phase transformations were detected with analysis of sample 21 . The first one at $278^{\circ} \mathrm{C}$ is related to $\mathrm{L}+\eta \rightarrow \xi+(\mathrm{Bi})$ reaction calculated at $270.46^{\circ} \mathrm{C}$. The next one, detected at $549^{\circ} \mathrm{C}$, corresponds to $\mathrm{L}+\varepsilon \rightarrow \xi+\eta$ reaction and its calculated temperature is $549.31^{\circ} \mathrm{C}$. The third temperature, observed for sample 21 at $724^{\circ} \mathrm{C}$, matches to the $\mathrm{L} \rightarrow \mathrm{L}$ " $+\xi+\varepsilon$ reaction, calculated to be at $723.67^{\circ} \mathrm{C}$. The next recorded temperature at $766^{\circ} \mathrm{C}$ is related to the solidification of $\xi$ phase while the end temperature corresponds to a binodal phase transition. The same phase transformations were detected with analysis of samples 22 and 23. The first experimental temperatures for the both samples, 279 and $280{ }^{\circ} \mathrm{C}$, are related to a ternary eutectic reaction $\mathrm{L} \rightarrow(\mathrm{Ge})+(\mathrm{Bi})+\eta$ calculated at $271.07^{\circ} \mathrm{C}$. The second experimental temperatures, 615 and $616^{\circ} \mathrm{C}$, are related to $\theta \rightarrow \mathrm{L}+(\mathrm{Ge})+\eta$ reaction calculated at $611.64{ }^{\circ} \mathrm{C}$. The third detected temperatures for the same samples, 631 and $632{ }^{\circ} \mathrm{C}$, are related to the $\mathrm{L}^{\prime} \rightarrow \mathrm{L} "+(\textrm{Ge})+\theta$ transition with the calculated temperature of $623.05{ }^{\circ} \mathrm{C}$. The last recorded temperatures are associated with a binodal phase transition and liquid. Five temperatures were detected with testing of sample 24 . The first three experimentally detected temperatures $\left(278,615\right.$ and $\left.628^{\circ} \mathrm{C}\right)$ are related to $\mathrm{L} \rightarrow(\mathrm{Ge})+(\mathrm{Bi})+\eta$ reaction calculated at $271.07{ }^{\circ} \mathrm{C}$, $\theta \rightarrow \mathrm{L}+(\mathrm{Ge})+\eta$ calculated at $611.64^{\circ} \mathrm{C}$ and $\mathrm{L}, \rightarrow \mathrm{L} "{ }^{\prime}+(\mathrm{Ge})+\theta$ reaction calculated at $623.05{ }^{\circ} \mathrm{C}$, respectively. The forth temperature $733{ }^{\circ} \mathrm{C}$ is associated with the transformation of $\mathrm{L}+(\mathrm{Ge})$ into $\mathrm{L}+\mathrm{L}$ " $+(\mathrm{Ge})$ while the last one correspond to the transition to the liquid single phase region. 
As a general conclusion after the comparison of the experimental temperatures and the calculated vertical sections it can be said that a fairly close agreement is reached in most cases.

Two solidification simulations were performed for an alloy with 80 at $\%$ of $\mathrm{Cu}, 10$ at $\%$ of $\mathrm{Bi}$ and 10 at $\%$ of $\mathrm{Ge}$,

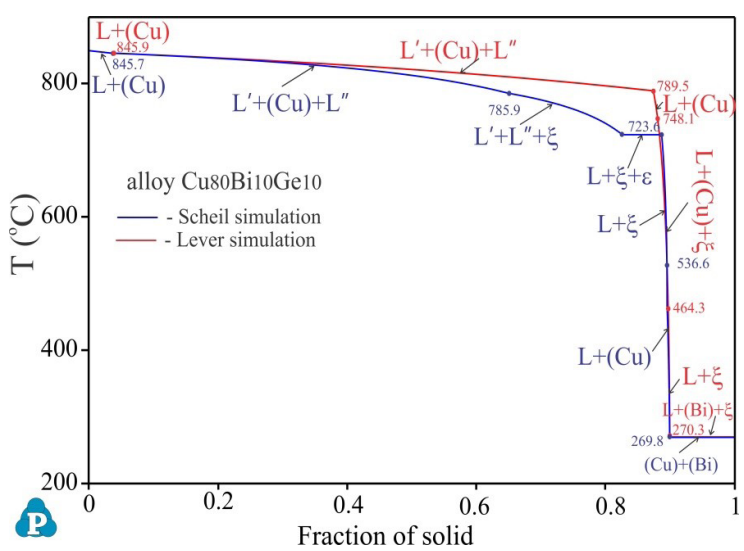

Figure 10. Scheil and Lever simulation results for alloy $\mathrm{Cu}_{80} \mathrm{Bi}_{10} \mathrm{Ge}_{10}$. which are compared in Figure 10. The equilibrium (Lever) and non-equilibrim (Scheil) simulations are given as a red and a blue line, respectively.

As expected, the differences between the simulation results are clearly visible. The solidifiction simulation in non-equilibrium conditions starts at $845.7^{\circ} \mathrm{C}$ and ends at $269.8^{\circ} \mathrm{C}$, the freezing range being $575.9^{\circ} \mathrm{C}$. The primary solidified phase is $(\mathrm{Cu}), \xi$ phase starts to solidify at $785.9^{\circ} \mathrm{C}$, $\varepsilon$ at $723.6{ }^{\circ} \mathrm{C}$ and (Bi) starts to solidify at $269.8^{\circ} \mathrm{C}$. In total four phases solidify during the freezing range $\left(575.9^{\circ} \mathrm{C}\right)$. Equilibrium solid (Lever) simulation marked as red line, shows start of solidification at $845.9{ }^{\circ} \mathrm{C}$ and its end at $270.3^{\circ} \mathrm{C}$. Firstly $(\mathrm{Cu})$ phase starts to solidify, followed by $\xi$ at $748.1{ }^{\circ} \mathrm{C}$ and lastly (Bi) at $270.3{ }^{\circ} \mathrm{C}$. During the freezing range $\left(575.6{ }^{\circ} \mathrm{C}\right)$ three phases solidify. After the conducted solidification simulations some follow-up properties can be calculated, as shown on Figures 11 and 12.

Detailed information regarding the simulation, such as solidification start temperature for a certain phase, the total fraction of each solid at different temperatures, latent heat, and total heat evolved can be found in the default table (in Pandat) after solidification simulations. Certain properties can be selected from the Default table and plotted. Figure 11a, b show the fraction of each solid phase as a
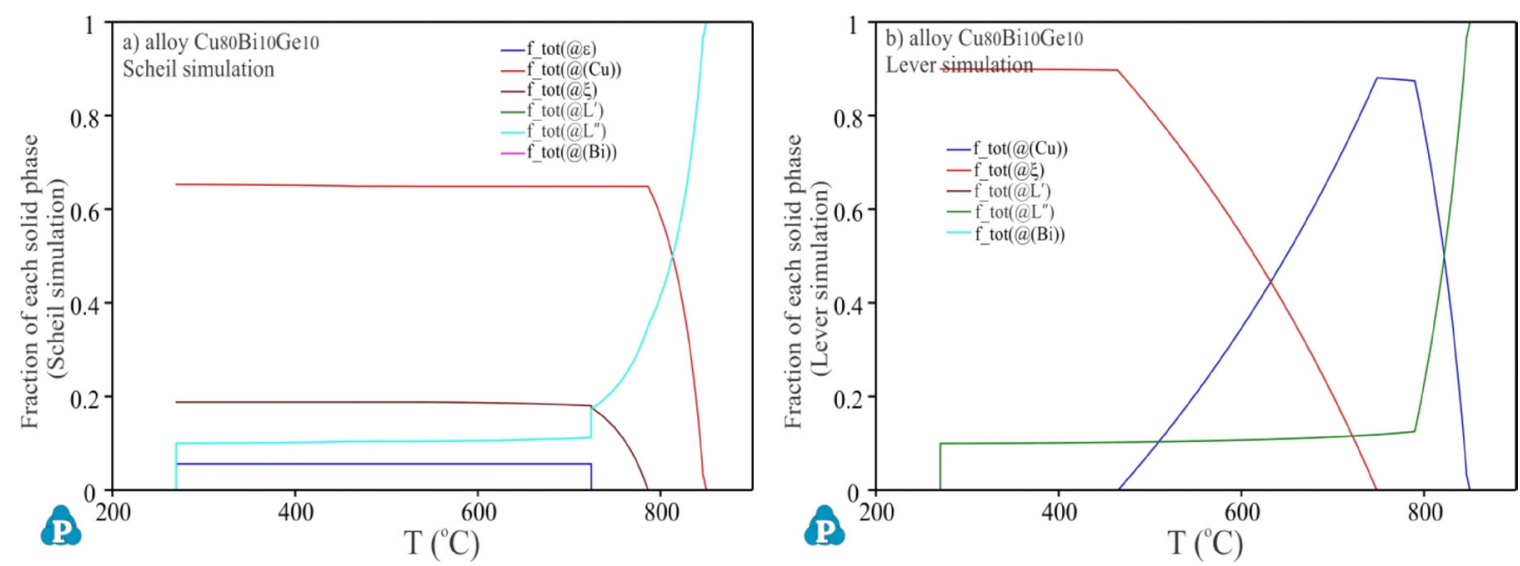

Figure 11. Fraction of each solid phase as a function of temperature for alloy $\mathrm{Cu}_{80} \mathrm{Bi}_{10} \mathrm{Ge}_{10}$, a) Scheil simulation and b) Lever simulation.
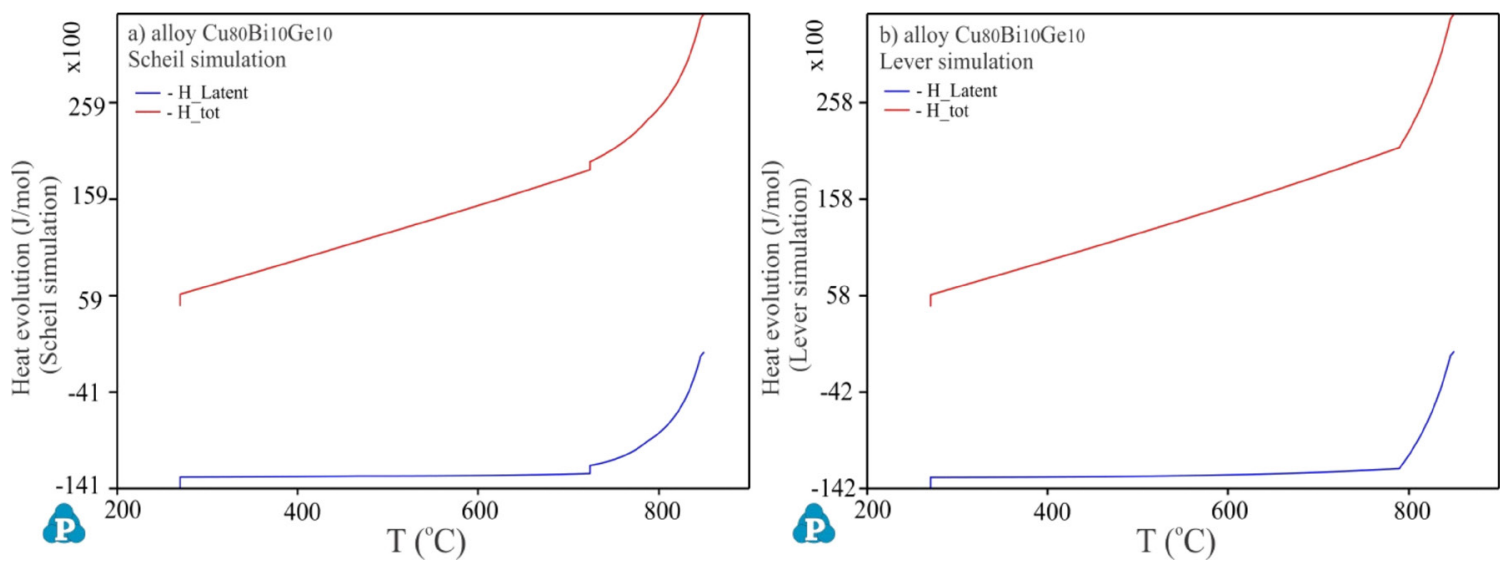

Figure 12. Heat evolution as a function of temperature for alloy $\mathrm{Cu}_{80} \mathrm{Bi}_{10} \mathrm{Ge}_{10}$, a) Scheil simulation and b) Lever simulation. 
function of temperature, and Figure 12a, b show the latent heat and total heat evolution as a function of temperature.

\section{Conclusion}

The ternary Bi-Cu-Ge system was experimentally investigated and Thermodynamically calculated using the Calphad approach. Twenty-four ternary samples were prepared and tested using DTA, SEM-EDS and XRD. The thermodynamic calculations included calculation of three vertical sections and two isothermal sections at 400 and $600{ }^{\circ} \mathrm{C}$.

The isothermal section at $600^{\circ} \mathrm{C}$ was investigated with analysis of six ternary alloys and four different phase regions were detected. Six ternary alloys were also analyzed for the investigation of the isothermal section at $400{ }^{\circ} \mathrm{C}$ and three different phase regions were detected. The experimental results did not point to the stability of new ternary compounds or to large solubility of the components in the binary intermetallic compounds and solid solutions.

Three vertical sections were calculated from each corner $\mathrm{Bi}, \mathrm{Cu}$ and $\mathrm{Ge}$. Four samples from the each vertical section were tested by DTA. The obtained DTA results and recorded temperatures of phase transformations were found to be in a close agreement with the calculated temperatures.

The good agreement between experimental results and calculated sections of the ternary Bi-Cu-Ge system support the direct use of extrapolations from the thermodynamic descriptions of the binaries to the ternary without using adjustment parameters.

\section{Acknowledgements}

This work has been supported by the National Nature Science Foundation of China (project No.51950410600) and the Ministry of Education, Science and Technological Development of the Republic of Serbia (Grant No. OI172037).

\section{References}

1. Tichy L, Tichá H, Pacesová A, Petzlt J. On the infrared spectra of Ge-Bi-Se(S) glasses. J Non-Cryst Solids. 1991;128(2):191-6.

2. Adachi S. Properties of semiconductor alloys: group-IV, III-V and II-VI, semiconductors. Hoboken: Wiley; 2009.

3. Rockett A. The materials science of semiconductors. Springer: Berlin; 2008.

4. Burr GW, Kurdi BN, Scott JC, Lam CH, Gopalakrishnan K, Shenoy RS. Overview of candidate device technologies for storage-class memory. IBM J Res Develop. 2008;52(4-5):449-64.

5. Vasić MM, Kalezić-Glišović AS, Milinčić R, Radović LJ, Minić DM, Maričić AM, et al. Influence of mechanical activation and heat treatment on magnetic properties of nanostructured mixture Ni85.8Fe10.6Cu2.2W1.4. J Min Metall Sect B-Metall. 2019;55(1):85-93.
6. Azimi M,Akbari GH. Characterization of nano-structured $\mathrm{Cu}-6$ wt.\% Zr alloy produced by mechanical alloying and annealing methods. J Alloys Compd. 2013;555:112-6.

7. Kobayashi Y, Shirochi T, Yasuda Y, Morita T. Synthesis of silver/ copper nanoparticles and their metal-metal bonding property. J Min Metall Sect B-Metall. 2013;49(1):65-70.

8. Samal CP, Parihar JS, Chaira D. The effect of milling and sintering techniques on mechanical properties of $\mathrm{Cu}$-graphite metal matrix composite prepared by powder metallurgy route. J Alloys Compd. 2013;569:95-101.

9. Brodarac ZZ, Dolić N, Unkić F. Influence of copper content on microstructure development of A1Si9Cu3 alloy. J Min Metall Sect B-Metall. 2014;50(1):53-60.

10. Djordjevic A, Premovic M, Minic D, Cosovic V, Manasijevic D. Experimental examination and thermodynamic description of the ternary Bi-Ge-Ga,Zn systems. J Chem Thermodyn. 2020;142:106000

11. Djordjević A, Minić D, Premović M, Manasijević D, Ćosović V. Experimental examination and thermodynamic description of the ternary Bi-Ge-In and -Sn Systems. J Phase Equilib Diffus. 2019;40:623-37.

12. Milisavljević D, Minić D, Premović M, Manasijević D, Ćosović V, Košanin N. Combined thermodynamic description and experimental investigation of the ternary $\mathrm{Ag}-\mathrm{Bi}-\mathrm{Ge}$ System. Int J Thermophys. 2019;40:29.

13. Teppo O, Niemela J, Taskinen P. An assessment of the thermodynamic properties and phase diagram of the system Bi-Cu. Thermochim Acta. 1990;173:137-50.

14. Wang J, Jin S, Leinenbach C, Jacot A. Thermodynamic assessment of the Cu-Ge binary system. J Alloys Compd. 2010;504:159-65.

15. Chevalier PY. Thermodynamic evaluation of the Bi-Ge system. Thermochim Acta. 1988;132:111-6.

16. Barrett CS. The structure of bismuth at low temperatures. Aust J Phys. 1960;13:209-22.

17. Halder SK, Sen G. An X-ray determination of the thermal expansion of silver and copper-base alloys at high temperature. II. Cu-Ga. Acta Crystallogr A. 1975;31:158-9.

18. Cooper AS. Precise lattice constants of germanium, aluminum, gallium arsenide, uranium, sulphur, quartz and sapphire. Acta Crystallogr. 1962;15:578-82.

19. Schubert K, Brandauer G. Zum aufbau des systems kupfergermanium. Z Metallkd. 1952;43:262-8.

20. Glasov VM, Potemkin AY. Interaction between copper and antimony in a solid solution based on germanium with the formation of a charged complex. Semiconductors. 2000;34(5):495-501.

21. Schubert K, Breimer H, Burkhardt W, Gunzel E, Haufler R, Lukas HL, et al. Einige strukturelle Ergebnisse anmetallischen Phasen II. Naturwissenschaften. 1957;44(7):229-30.

22. Lenz J, Schubert K. Uebereinige leerstellen- und stapelvarianten der beta-messing strukturfamilie. Z Metallkd. 1971;62:810-6.

23. Fima P, Gazda A. Thermal analysis of selected $\mathrm{Sn}-\mathrm{Ag}-\mathrm{Cu}$ alloys. J Therm Anal Calorim. 2013;112:731-7.

24. Boettinger WJ, Kattner UR, Moon KW, Perepezko JH. DTA and heat-flux DSC measurements of alloy melting and freezing. In: Zhao, J, editor. Methods for phase diagram determination. Kidlington: Elsevier Science; 2007. 